\title{
PENGARUH PEMBIAYAAN BAGI HASIL DAN PEMBIAYAAN JUAL BELI TERHADAP PROFITABILITAS DENGAN NON PERFORMING FINANCING (NPF) SEBAGAI VARIABEL INTERVENING
}

\author{
Ainun Mufarida1), Lu'lu'il Maknuun²), Rahman Yusri Aftian³) \\ Institut Pesantren KH Abdul Chalim, Mojokerto, Indonesia \\ 1)ainunmufarida04@gmail.com, 2)luluilmaknuun92@gmail.com, 3)aftian9603@gmail.com
}

\begin{abstract}
Abstrak. Pembiayaan merupakan suatu produk dalam dunia perbankan yang dinilai mampu meningkatkan profitabilitas. Akan tetapi produk pembiayaan juga dapat meningkatkan tingkat Non Performing Financing dalam suatu bank. Sehingga bank harus lebih berhati-hati dalam menyalurkan pembiayaan. Tujuan dari penelitian ini adalah untuk mengetahui pengaruh pembiayaan bagi hasil dan pembiayaan jual beli terhadap profitabilitas dengan NPF sebagai variabel intervening pada bank umum syariah periode 2015-2019. Data yang digunakan dalam penelitian ini adalah data sekunder yang diperoleh dari laporan tahunan bank umum syariah. Teknik pengambilan sampel dilakukan dengan teknik purposive sampling yang menghasilkan sampel sebanyak 11 bank umum syariah dengan kurun waktu 5 periode. Alat analisis yang digunakan dalam penelitian ini adalah SmartPLS.

Hasil penelitian menunjukkan bahwa terdapat pengaruh positif signifikan pembiayaan bagi hasil terhadap profitabilitas. Terdapat pengaruh positif signifikan pembiayaan bagi hasil terhadap Non Performing Financing (NPF). Terdapat pengaruh positif signifikan pembiayaan jual beli terhadap Non Performing Financing (NPF). Terdapat pengaruh positif signifikan pembiayaan jual beli terhadap profitabilitas. Terdapat pengaruh negatif signifikan Non Performing Financing (NPF) terhadap profitabilitas.
\end{abstract}

Kata Kunci: Pembiayaan bagi hasil, pembiayaan jual beli, profitabilitas, dan NPF

\begin{abstract}
Financing is a product in the banking world that is considered capable of increased profitability. However, financing product can also increased the level of Non Performing Financing in a bank. So that bank must be careful in distributed financing. The purpose of this research is to knew the influence of profit sharing financing and sale and purchase financing to profitability with non performing financing (NPF) as intervening variable in islamic commercial banks period 2015-2019. This research used secondary data from the annual reports of Islamic commercial banks. The sampling technique used is purposive sampling technique and it is obtained in as sample of this research 11 islamic bank with a period of 5 periods. The analytical tool used in this research is SmartPLS.The results show that there is a significant positive influence on profit sharing financing to profitability. There is a significant positive on profit sharing financing to Non Performing Financing (NPF). There is a significant positive on sale and purchase financing to Non Performing Financing (NPF). There is a significant positive on sale and purchase financing to profitability. There is a significant negative on Non Performing Financing (NPF) to profitability.
\end{abstract}

Keyword: Profit sharing financing, sale and purchase financing, profitability, and NPF 


\section{PENDAHULUAN}

Perkembangan perekonomian yang semakin meningkat membuat persaingan yang terjadi antar lembaga keuangan yang ada di Indonesia semakin lama juga semakin meningkat. Hal ini dapat dibuktikan dengan semakin banyaknya lembaga keuangan yang membuka beberapa kantor cabang, yang dibantu oleh kantor cabang pembantu, serta kantor kas pada setiap daerah yang ada di Indonesia. Salah satu diantara lembaga keuangan tersebut adalah lembaga perbankan. Lembaga perbankan merupakan suatu instrumen yang penting bagi pemerintah. Lembaga perbankan memiliki peran yang penting dalam mengendalikan kebijakan keuangan moneter, menstabilkan sistem keuangan, serta meningkatkan pertumbuhan perekonomian dalam suatu negara. ${ }^{1}$

Bank Syariah mulai muncul di Indonesia pada tahun 1992 dimana bank Syariah pertama di Indonesia adalah Bank Muamalat. Hal ini menjadi tantangan tersendiri bagi bank Syariah, karena jauh sebelum bank Syariah didirikan, masyarakat Indonesia sudah terlebih dahulu mengenal bank konvensional yang sudah ada sejak zaman Belanda. Bank Syariah dituntut untuk dapat bersaing dengan bank konvensional, bank-bank asing, serta lembaga keuangan lainnya. Semakin banyaknya jumlah bank yang ada, maka persaingan antar sesama bank itu sendiri pun semakin meningkat atau semakian tinggi.

Bank Syariah sendiri memiliki peranan yang penting dalam perekenomian bangsa Indonesia. Salah satunya adalah peranan bank Syariah dalam aktifitas penyaluran dana kepada masyarakat. Dana tersebut nantinya akan digunakan sebagai modal usaha oleh para nasabah yang mengajukan permohonan pembiayaan, serta juga digunakan untuk memenuhi kebutuhan konsumsi sehari-hari. Selain bertugas untuk menyalurkan dana, bank Syariah juga memberikan jasa berupa pelayanan yang baik untuk memudahkan masyarakat dalam melakukan transaksi.

Penyaluran produk pembiayaan yang disalurkan oleh bank syariah diharapkan dapat meningkatkan profitabilitas dalam bank syariah tersebut. Sehingga tingkat profitabilitas yang didapatkan dalam bank juga semakin meningkat. Adapun produk pembiayaan dalam bank syariah sendiri terbagi menjadi dua jenis pembiayaan yaitu pembiayaan dengan akad bagi hasil dan pembiayaan dengan akad jual beli. Kedua pembiayaan ini sama-sama dijalankan dan disalurkan dengan menerapkan prinsip-prinsip syariah, serta diawasi langsung oleh

\footnotetext{
${ }^{1}$ https://www.ojk.go.id/ (diakses pada tanggal 08 Februari 2021, pukul 12.00).
} 
dewan pengawas syariah. Hal ini yang membedakan sistem pembiayaan pada bank syariah dengan pembiayaan pada bank konvensional.

Prinsip pembiayaan bagi hasil pada bank Syariah dapat diukur melalui empat indikator yaitu melalui akad al musyarakah, al mudharabah, al muzara'ah, dan al musaqah. ${ }^{2}$ Dari keempat indikator tersebut yang paling diminati oleh nasabah adalah pembiayaan bagi hasil dengan akad mudharabah dan akad musyarakah. Pembiayaan mudharabah dan pembiayaan musyarakah disalurkan untuk dapat membantu nasabah dalam memenuhi kebutuhan mereka untuk menjalankan usaha yang mereka miliki, sesuai syarat dan ketentuan yang sudah ditetapkan. Yang membedakan kedua akad tersebut adalah terletak pada modal yang diberikan. Pada akad mudharabah dana atau modal seratus persen berasal dari shahibul maal, sedangkan mudharib hanya bertugas untuk mengolah dana agar mendapatkan keuntungan. Sedangkan pada akad musyarakah masing-masing pihak samasama memberikan kontribusi dana, sehingga kedua pihak yang berakad sama-sama berperan sebagai shahibul maal dan sebagai mudharib.

Selain produk pembiayaan dengan menggunakan prinsip bagi hasil, bank Syariah juga mempunyai produk pembiayaan dengan prinsip jual beli yang digunakan untuk menyalurkan dana yang mereka miliki kepada masyarakat. Produk dari bank yang didasarkan pada akad jual beli meliputi pembiayaan dengan menggunakan indikator berupa akad murabahah, salam, dan istishna ${ }^{3}$. Produk pembiayaan jual beli ini nantinya akan disalurkan pada masyarakat sesuai dengan akad yang telah disetujui atau disepakati oleh pihak bank dan nasabah. Yang pertama ada akad murabahah dapat diartikan sebagai suatu perjanjian yang dilakukan antara pihak bank dan nasabah dalam bentuk pembiayaan pembeliaan atas suatu barang yang sedang dibutuhkan oleh nasabah. ${ }^{4}$ Yang kedua akad salam adalah pembelian barang yang diserahkan di kemudian hari, sedangkan untuk pembayarannya dilakukan dimuka. Selanjtnya akad istishna merupakan akad yang hampir sama dengan akad salam yaitu jual beli dengan melakukan pemesanan terlebih dahulu. Perbedaan antara akad salam dan akad istishna terletak pada cara pembayaran. Jika dalam akad salam pemesan harus membayar terlebih dahulu barang yang mereka pesan, sedangkan dalam akad istishna

\footnotetext{
2 Kasmir. Dasar-Dasar Perbankan Edisi Revisi 2014( Jakarta: Raja Grafindo Persada,2015), hal. 247.

3 Khotibul Umam. Perbankan Syariah (Dasar-dasar dan Dinamika Perkembangannya di Indonesia) ( Jakarta: Rajawali Press, 2016), hal.103.

${ }^{4}$ Suhrawardi K. Lubis. Hukum Ekonomi Islam ( Jakarta : Sinar Grafika, 2000), hal.62.
} 
pemesan dibolehkan melakukan pembayaran di muka baik secara tunai, diangsur, ataupun membayar ketika barang yang mereka pesan telah datang. ${ }^{5}$

Tingginya tingkat pembiayaan yang disalurkan oleh bank Syariah tentu akan berpengaruh terhadap profitabilitas dari bank tersebut. Semakin tinggi tingkat pembiayaan yang disalurkan oleh pihak bank maka semakin tinggi pula profitabilitas yang dihasilkan oleh bank tersebut. Hal ini sejalan dengan penelitian yang dilakukan oleh Budihariyanto, Afifudin, Junaidi $^{6}$; Dwi Wahyuningsih ${ }^{7}$; Yulinda Wayuning Arum $^{8}$ yang menyatakan jika variabel pembiayaan berpengaruh signifikan terhadap profitabilitas. Akan tetapi hal ini berbanding terbalik dengan penelitian yang dilakukan oleh Mila Rosa, Neny Tri Indrianasari, Khoirul Ifa ${ }^{9}$ yang menyatakan jika variabel pembiayaan tidak berpengaruh terhadap profitabilitas suatu bank.

Meningkatnya pembiayaan pada suatu bank tentu harus diiringi dengan manajemen keuangan yang baik, karena kegiatan pembiayaan yang dilakukan oleh pihak bank Syariah tentu tidak terlepas dengan adanya risiko pembiayaan bermasalah atau yang biasanya disebut dengan Non Performing Financing. Oleh sebab itu kualitas pembiayaan berkaitan erat dengan risiko pembiayaan bermasalah dari suatu produk yang disalurkan. Artinya semakin berkualitas pembiayaan yang diberikan maka akan mampu untuk memperkecil risiko terhadap terjadinya kredit macet atau bermasalah. Semakin banyaknya kredit macet yang terjadi maka akan membuat keuntungan yang dihasilkan oleh suatu bank semakin menurun.

Peningkatan nilai NPF akan sangat berdampak pada perolehan profitabilitas dalam suatu bank syariah. Hal ini membuat bank syariah harus benar-benar memperhatikan kualitas pembiayaan yang akan disalurkan. Kualitas pembiayaan yang disalurkan oleh bank sangat berkaitan erat dengan risiko pembiayaan bermasalah atau kredit macet. Artinya semakin berkualitas pembiayaan yang disalurkan, maka risiko kredit macet akan menjadi kecil atau risiko tersebut dapat diminimalisir. Dalam dunia perbankan pembiayaan

5 Khotibul Umam, Perbankan Syariah........, hal. 103.

6 Budihariyanto, Afifudin, Junaidi, "Pengaruh Pembiayaan (Bagi Hasil dan Jual Beli), Financing To Deposit Ratio (FDR), dan Non Performing Financing (NPF) Terhadap Profitabilitas Bank Non Devisa Syariah". Jurnal Ekonomi Vol. 07 No. 04, Agustus 2018.

7 Dwi Wahyuningsih, Skripsi : "Pengaruh Pembiayaan Jual Beli, Pembiayaan Bagi Hasil, Likuiditas, Dan Intellectual Capital Terhadap Profitabilitas” (Surakarta : IAIN Surakarta, 2019).

8 Yulinda Wahyuning Arum, Skripisi : "Pengaruh Pembiayaan Jual Beli Dan Pembiayaan Bagi Hasil Terhadap Return On Asset Bank Umum Syariah" ( Ponorogo : IAIN Ponorogo, 2019).

${ }^{9}$ Mila Rosa, Neny Tri Indrianasari, Khoirul Ifa, "Pengaruh Pembiayaan Jual Beli, Pembiayaan Bagi Hasil, Dan Rasio Non Performing Financing Terhadap Profitabilitas (Studi Empirs pada Bank Umum Syariah di Bursa Efek Indonesia Tahun 2012-2017". Jurnal Ekonomi Vol. 2, Juli 2019. 
merupakan unsur utama untuk meningkatkan profitabilitas yang didapatkan. Artinya besarnya keuntungan yang diperoleh oleh suatu bank sangatlah dipengaruhi oleh jumlah pembiayaan yang dapat disalurkan kepada masyarakat. Semakin tinggi pembiayaan yang disalurkan maka keuntungan yang didapat oleh bank akan semakin tinggi. ${ }^{10}$

Sehingga latar belakang peneliti mengambil penelitian dengan judul ini karena peneliti ingin mengetahui berbagai macam permasalahan yang ada dalam produk pembiayaan yang disalurkan oleh bank Syariah. Hal ini dilakukan karena semakin tingginya tingkat pembiayaan yang diberikan oleh bank Syariah baik itu pembiayaan bagi hasil maupun pembiayaan jual beli selain dapat meningkatkan tingkat profitabilitas bank tersebut, juga akan dapat menimbulkan risiko pembiayaan bermasalah yang timbul karena adanya kredit macet atau nasabah tidak mampu mengembalikan dana yang telah mereka pinjam. Ketika hal ini terjadi maka profitabilitas pada bank Syariah akan mengalami penurunan, yang disebabkan karena meningkatnya nilai NPF. Berdasarkan latar belakang diatas didapatkan rumusan masalah sebagai berikut :

1. Apakah pembiayaan bagi hasil berpengaruh signifikan terhadap profitabilitas bank Syariah?

2. Apakah pembiayaan bagi hasil berpengaruh signifikan terhadap non performing financing bank Syariah?

3. Apakah pembiayaan jual beli berpengaruh signifikan terhadap non performing financing bank Syariah?

4. Apakah pembiayaan jual beli berpengaruh signifikan terhadap profitabilitas bank Syariah?

5. Apakah non performing financing berpengaruh signifikan terhadap profitabilitas bank Syariah?

Adapun tujuan dari penelitian ini adalah sebagai berikut :

1. Untuk mengetahui dan menganalisis pengaruh pembiayaan bagi hasil terhadap profitabilitas.

2. Untuk mengetahui dan menganalisis pengaruh pembiayaan bagi hasil terhadap non performing financing.

3. Untuk mengetahui dan menganalisis pengaruh pembiayaan jual beli terhadap non performing financing .

10 Kasmir, Dasar-dasar Perbankan ........., hal. 125. 
4. Untuk mengetahui dan menganalisis pengaruh pembiayaan jual beli terhadap profitabilitas.

5. Untuk mengetahui dan menganalisis pengaruh non performing financing terhadap profitabilitas.

\section{LITERATUR REVIEW}

\begin{tabular}{|c|c|c|c|}
\hline NO & Judul & Peneliti dan Tahun & Hasil \\
\hline \multirow[t]{4}{*}{1} & $\begin{array}{l}\text { Pengaruh pembiayaan bagi } \\
\text { hasil, jual beli, FDR, NPF } \\
\text { terhadap profitabilitas } \\
\text { bank syariah }\end{array}$ & $\begin{array}{l}\text { Yulia Inayatillah, } \\
\text { Anang Subardjo, } 2017\end{array}$ & $\begin{array}{l}\text { 1. Variabel pembiayaan } \\
\text { bagi hasil tidak } \\
\text { berpengaruh terhadap } \\
\text { profitabilitas. } \\
\text { 2. Variabel pembiayaan } \\
\text { jual beli berpengaruh } \\
\text { positif terhadap } \\
\text { profitabilitas. } \\
\text { 3. Variabel NPF tidak } \\
\text { berpengaruh terhadap } \\
\text { profitabilitas. }\end{array}$ \\
\hline & Persamaan & \multicolumn{2}{|c|}{$\begin{array}{l}\text { Meneliti variabel pembiayaan bagi hasil, jual beli, NPF, } \\
\text { dan profitabilitas. }\end{array}$} \\
\hline & Perbedaan & \multicolumn{2}{|c|}{$\begin{array}{l}\text { Dalam penelitian ini variabel NPF digunakan sebagai } \\
\text { variabel intervening. }\end{array}$} \\
\hline & Manfaat & \multicolumn{2}{|c|}{$\begin{array}{l}\text { Penelitian ini berguna untuk mengetahui hubungan antar } \\
\text { variabel-variabel yang akan diuji, yakni variabel } \\
\text { pembiayaan bagi hasil, jual beli, NPF, dan profitabilitas. } \\
\text { Hasil dari penelitian ini berguna sebagai pembanding } \\
\text { untuk penelitian yang akan dilakukan. }\end{array}$} \\
\hline \multirow[t]{3}{*}{2} & $\begin{array}{l}\text { Pengaruh pembiayaan } \\
\text { (bagi hasil dan jual beli), } \\
\text { financing to deposit (FDR), } \\
\text { dan Non Performing } \\
\text { Financing (NPF) terhadap } \\
\text { profitabilitas pada bank } \\
\text { non devisa syariah }\end{array}$ & $\begin{array}{l}\text { Budihariyanto, } \\
\text { Afifudin, Junaidi, } 2018\end{array}$ & 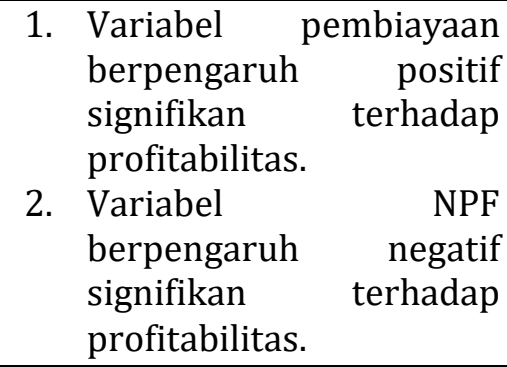 \\
\hline & Persamaan & \multicolumn{2}{|c|}{ Meneliti variabel pembiayaan dan profitabilitas. } \\
\hline & Perbedaan & \multicolumn{2}{|c|}{$\begin{array}{l}\text { Dalam penelitian ini variabel NPF dijadikan sebagai } \\
\text { variabel intervening. Objek penelitian pada penelitian ini } \\
\text { ialah bank umum syariah. }\end{array}$} \\
\hline
\end{tabular}




\begin{tabular}{|c|c|c|c|}
\hline 3 & $\begin{array}{l}\text { Pengaruh pembiayaan bagi } \\
\text { hasil, pembiayaan jual beli, } \\
\text { terhadap profitabilitas } \\
\text { (ROA) dengan Non } \\
\text { Performing Financing } \\
\text { (NPF) sebagai variabel } \\
\text { intervening }\end{array}$ & Lilis Sudarwati, 2018 & 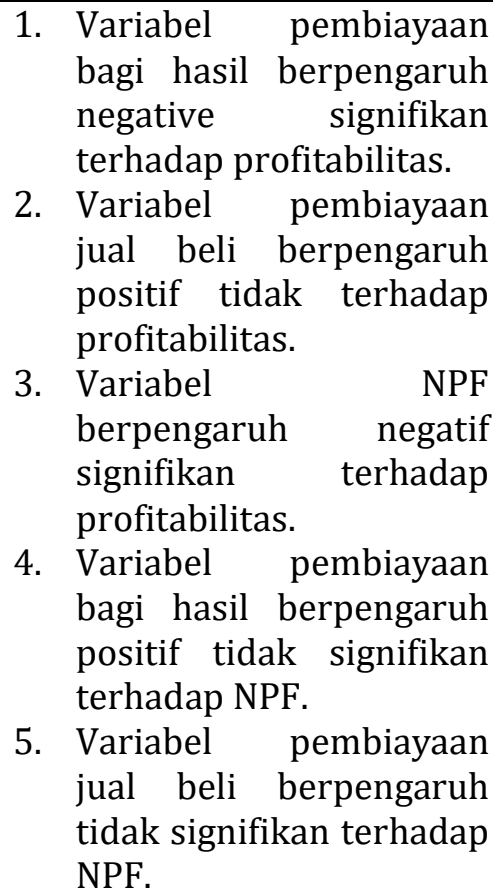 \\
\hline & Persamaan & \multicolumn{2}{|c|}{$\begin{array}{l}\text { Meneliti variabel pembiayaan jual beli, bagi hasil, NPF dan } \\
\text { profitabilitas. }\end{array}$} \\
\hline & Perbedaan & \multicolumn{2}{|c|}{$\begin{array}{l}\text { Objek penelitian pada penelitian ini ialah seluruh bank } \\
\text { umum syariah yang terdaftar pada OJK yakni sebanyak } 12 \\
\text { bank umum syariah. Penelitian ini dilakukan dari periode } \\
2015-2019 \text {. }\end{array}$} \\
\hline
\end{tabular}

\section{METODE PENELITIAN}

\section{Jenis dan Pendekatan Penelitian.}

Penelitian ini dilakukan dengan menggunakan pendekatan deskriptif kuantitatif. Pendekatan deskriptif kuantitatif adalah suatu metode yang dilakukan dengan tujuan untuk menjelaskan sebuah fenomena yang disertai dengan data statistik serta untuk menjelaskan hubungan antar variabel yang merupakan analisis pengaruh. ${ }^{11}$ Penelitian ini dilakukan dengan menggunakan metode kuantitatif karena untuk dapat mengetahui pengaruh pembiayaan bagi hasil, pembiayaan jual beli, dan Non Performing Financing (NPF) terhadap profitabilitas yang diperoleh oleh Bank Umum Syariah yang ada di Indonesia.

${ }^{11}$ Sugiyono, Metode Penelitian Kuantitatif, Kualitatif dan R\&D (Bandung : ALFABETA, 2011), hal. 5. 


\section{Variabel Penelitian}

Variabel penelitian yang digunakan dalam penelitian ini terdiri dari tiga jenis variabel yaitu variabel bebas (variabel eksogen), variabel terikat (variabel endogen), dan variabel intervening. Berikut variabel-variabel yang digunakan dalam penelitian ini :

\section{Variabel Penelitian}

\begin{tabular}{|c|l|l|}
\hline No & \multicolumn{1}{|c|}{ Variabel } & \multicolumn{1}{|c|}{ Indikator } \\
\hline 1 & \multirow{2}{*}{ Pembiayaan Bagi Hasil } & X1.1 Mudharabah \\
\cline { 3 - 3 } & & X1.2 Musyarakah \\
\hline 2 & \multirow{2}{*}{ Pembiayan Jual Beli } & X2.1 Murabahah \\
\cline { 3 - 3 } & & X2.2 Istishna \\
\cline { 3 - 3 } & & X2.3 Salam \\
\hline 3 & \multirow{2}{*}{ NPF } & NPF $=\frac{\text { Total Pembiayaan Bermasalah }}{\text { Total Pembiayaan }}$ X 100\% \\
& & \\
\hline 4 & \multirow{2}{*}{ Profitabilitas (ROA) } & Y.1 ROA \\
\cline { 3 - 4 } & & Y.2 ROE \\
\cline { 3 - 3 } & & Y.3 BOPO \\
\hline
\end{tabular}

\section{Populasi dan Sampel Penelitian}

Populasi penelitian dari penelitian ini adalah Bank Umum Syariah yang telah terdaftar pada Otoritas Jasa Keuangan pada tahun 2019. Bank Umum Syariah yang ada di Indonesia terdiri dari 14 bank yaitu Bank Aceh Syariah, BPD Nusa Tenggara Barat Syariah, Bank Jabar Banten Syariah, Bank Muamalat Indonesia, Bank Victoria Syariah, Bank BRI Syariah, Bank Syariah Mandiri, Bank BNI Syariah, BCA Syariah, Bank Mega Syariah, Bank Panin Dubai Syariah, Bank Syariah Bukopin, Bank Tabungan Pensiun Nasional Syariah, dan Maybank Syariah Indonesia ${ }^{12}$.

Sampel adalah bagian dari jumlah dan karakteristik yang mampu mewakili suatu populasi. ${ }^{13}$ Sampel adalah bagian dari populasi yang memiliki karakteristik khusus sehingga mampu mewakili suatu populasi yang dijadikan sebagai objek penelitian. Pengambilan sampel pada penelitian ini menggunakan teknik Purposive sampling. Teknik ini adalah teknik yang dalam penentuan sampelnya dilakukan dengan cara melakukan pertimbangan khusus.

\footnotetext{
12 https://www.ojk.go.id/ (Diakses pada tanggal 23 Maret 2021, pukul 19.39)

${ }^{13}$ Sugiyono, Metode Penelitian Kombinasi (Mixed Methods) (Bandung : Alfabeta, 2013), hal. 120.
} 


\section{Daftar Bank Umum Syariah}

\begin{tabular}{|c|l|}
\hline No & \multicolumn{1}{|c|}{ Nama Bank Umum Syariah } \\
\hline 1 & Bank Muamalat Indonesia \\
\hline 2 & Bank Victoria Syariah \\
\hline 3 & Bank BRI Syariah \\
\hline 4 & Bank Jabar Banten Syariah \\
\hline 5 & Bank BNI Syariah \\
\hline 6 & Bank Syariah Mandiri \\
\hline 7 & Bank Mega Syariah \\
\hline 8 & Bank Panin Syariah \\
\hline 9 & Bank Syariah Bukopin \\
\hline 10 & BCA Syariah \\
\hline 11 & Bank Tabungan Pensiun Nasional Syariah \\
\hline
\end{tabular}

Sumber : Statistik Perbankan Syariah 2015.

\section{Teknik Pengumpulan Data}

Teknik pengumpulan data adalah proses atau langkah-langkah yang dilakukan oleh peneliti untuk mengumpulkan data yang dibutuhkan untuk penelitian yang sedang dilakukan. Teknik pengumpulan data pada penelitian ini menggunakan teknik observasi tidak langsung. Teknik observasi tidak langsung dilakukan dengan cara melakukan pengamatan secara jarak jauh atau tidak langsung terhadap laporan keuangan tahunan bank umum syariah. Jenis data yang digunakan dalam penelitian ini adalah data sekunder yang didapat dari laporan keuangan Bank Umum Syariah di Indonesia. Data laporan keuangan tahunan bank umum syariah tahun 2015 sampai 2019 ini didapatkan dari website Otoritas Jasa Keuangan dan website bank yang terkait.

\section{Teknik Analisis Data}

Teknik analisis data adalah suatu cara yang digunakan peneliti untuk dapat menjawab rumusan masalah serta untuk menguji hipotesis yang telah dirumuskan oleh peneliti. ${ }^{14}$ Peneliti menggunakan alat analisis berupa pendekatan Partial Least Square (PLS) untuk melakukan analisis data. Software yang digunakan adalah SmartPLS 3.0. PLS adalah salah satu metode dalam statistika SEM yang memiliki basis varian yang didesain untuk dapat menyelesaikan regresi berganda apabila terjadi permasalahan terhadap spesifik data, seperti ukuran sampel penelitian yang kecil, adanya data yang hilang dan multikolonieritas. ${ }^{15}$

\footnotetext{
14 Sugiyono, Metode Penelitian Kombinasi (Mixed Methods)..., hal. 331

15 Hartono M Jogiyanto, Analisis dan Disain: Sistem Informasi: Pendekatan Tersturktur Teori dan Praktek Aplikasi Bisnis, (Yogyakarta: C.V Andi Offset, 2009), hal. 11.
} 
Langkah-langkah yang harus dilakukan dalam melakukan analisis data dengan menggunakan sistem PLS adalah sebagai berikut :

\section{Model Pengukuran (Outer Model)}

Sebelum melakukan suatu pengujian berupa model prediksi hubungan relasional dan kausal harus melewati tahap verifikasi. Adapun tahap verifikasi dalam pendekatan PLS adalah melalui model pengukuran atau yang biasanya disebut dengan outer model. Outer model dalam pendekatan PLS dilakukan untuk menjelaskan hubungan antara indikator dengan variabel latennya. Terdapat dua model pengukuran dalam outer model yaitu dengan melakukan uji validitas dan uji reliabilitas. ${ }^{16}$

\section{Merancang model struktual atau yang biasa disebut dengan inner model.}

Model struktural (Inner Model) adalah model struktural yang digunakan untuk menciptakan prediksi hubungan sebab akibat antar variabel. Setelah model yang diperkirakan dapat memenuhi kriteria pengukuran Outer Model, selanjutnya akan dilakukan pengujian berupa model struktural(Inner model). Model struktural dalam PLS nantinya akan dievaluasi dengan menggunakan tingkat nilai $\mathrm{R}^{2}$ atau yang biasa disebut dengan uji $R$ Squared dan Q-square. Nilai $\mathrm{R}^{2}$ digunakan peneliti untuk dapat mengukur tingkat perubahan variabel bebas terhadap variabel terikat. ${ }^{17}$ Semakin tinggi nilai $\mathrm{R}^{2}$ berarti semakin baik juga model prediksi dari model penelitian yang telah diajukan oleh peneliti.

\section{Hipotesis Penelitian}

Hipotesis dalam penelitian ini adalah sebagai berikut :

1) $\mathrm{H}_{1}$ : Pembiayaan bagi hasil berpengaruh signifikan terhadap profitabilitas.

2) $\mathrm{H}_{2}$ : Pembiayaan bagi hasil berpengaruh signifikan terhadap Non Performing Financing (NPF).

3) $\mathrm{H}_{3}$ : Pembiayaan jual beli berpengaruh signifikan terhadap Non Performing Financing (NPF).

4) $\mathrm{H}_{4}$ : Pembiayaan jual beli berpengaruh signifikan terhadap profitabilitas.

5) $\mathrm{H}_{5}$ : Non Performing Financing (NPF) berpengaruh signifikan terhadap profitabilitas.

16Willy Abdilah Dan Jogiyanto, Partial Least Square (PLS) Alternatif Struktural Equation Modeling (SEM) dalam Penelitian Bisnis, (Yogyakarta: C.V Andi Offset, 2015), hal. 194.

17Willy Abdilah Dan Jogiyanto, Partial Least Square (PLS)............, hal. 197. 


\section{HASIL DAN PEMBAHASAN}

Hasil dari penelitian ini diolah dengan menggunakan SmartPLS versi 3.0. Adapun data yang digunakan dalam penelitian ini adalah data berupa laporan keuangan yang didapat dari 11 (sebelas) bank umum syariah yang terdaftar di Otoritas Jasa Keuangan (OJK) periode 2015-2019, sehingga diperoleh sampel sebanyak 55 data. Setelah mendapatkan semua data yang dibutuhkan, penulis akan melakukan proses tabulasi data sehingga data tersebut dapat diolah dalam aplikasi SmartPLS. Analisis data dengan menggunakan aplikasi SmartPLS versi 3.0 harus melalui beberapa tahapan yaitu outer model, inner model, dan uji hipotesis. Tahaptahap tersebut adalah sebagai berikut :

\section{Outer Model}

\section{Convergent Validity}

Convergent validity adalah besar nilai loading factor pada setiap variabel laten dengan indikator-indikatornya. Uji ini bertujuan untuk mengukur tingkat kevalidan anatar hubungan variabel dengan indikatornya. Suatu indikator dapat dikatakan valid ketika mendapatkan nilai loading factor $>0,5$.

\section{Kerangka Outer Model}

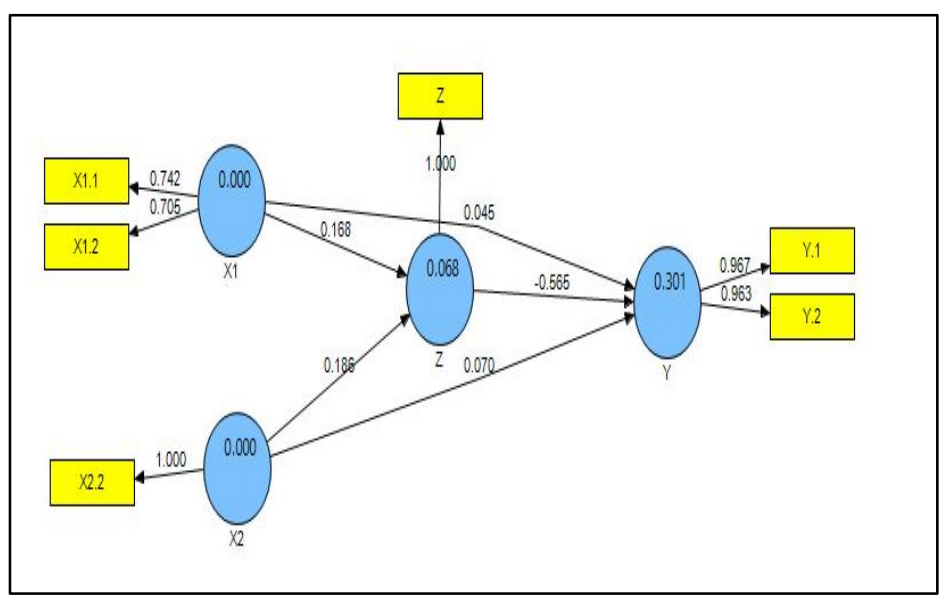

Sumber : Olah Data SmartPLS Versi 3.0 
Tabel Convergent Validity Modifikasi

\begin{tabular}{|l|r|r|r|r|}
\hline & NPF & $\begin{array}{l}\text { Pembiayaan } \\
\text { Bagi Hasil }\end{array}$ & $\begin{array}{l}\text { Pembiayaan } \\
\text { Jual Beli }\end{array}$ & Profitabilitas \\
\hline X1.1 & & 0.742 & & \\
\hline X1.2 & & 0.705 & & \\
\hline X2.2 & & & 1.000 & \\
\hline Y.1 & & & & 0.967 \\
\hline Y.2 & & & & 0.963 \\
\hline Z & 1.000 & & & \\
\hline
\end{tabular}

Sumber : Olah Data SmartPLS Versi 3.0

Berdasarkan hasil analisis pada data diatas dapat dilihat jika nilai loading factor dari setiap indikator $>0,5$ sehingga dapat dikatakan jika data tersebut memiliki tingkat kevalidan data yang baik dan dapat diproses ke tahap selanjutnya.

\section{Discriminant Validity}

Uji ini digunakan untuk menguji tingkat kevaliditasan setiap indikator. Hasil dari uji ini nantinya akan digunakan untuk mengetahui apakah nilai loading lebih besar dari nilai konstruk lainnya atau tidak.Suatu data dikatakan memiliki discriminant validity yang baik ketika memiliki nilai cross loading $>0.7$.

\section{Tabel Cross Loading}

\begin{tabular}{|c|c|c|c|c|}
\hline & NPF & $\begin{array}{c}\text { Pembiayaan } \\
\text { Bagi Hasil }\end{array}$ & $\begin{array}{c}\text { Pembiayaan } \\
\text { Jual Beli }\end{array}$ & Profitabilitas \\
\hline X1.1 & & 0.742 & & \\
\hline X1.2 & & 0.705 & & \\
\hline X2.2 & & & 1.000 & \\
\hline Y.1 & & & & 0.967 \\
\hline Y.2 & & & & 0.963 \\
\hline Z & 1.000 & & & \\
\hline
\end{tabular}

Sumber : Olah Data SmartPLS Versi 3.0

Tabel diatas menunjukkan bahwa discriminant validity yang dimiliki dari setiap konstruk baik sehingga data tersebut dapat dikatakan memiliki tingkat validitas yang baik. 


\section{Uji Reliabilitas}

Setelah data tersebut melalui tahap pengujian validitas, selanjutnya data tersebut akan melalui tahap pengujian reliabilitas dengan menggunkan nilai reliabilitas dari setiap konstruk atau variabel. Nilai yang digunakan untuk menilai tingkat realiabilitas adalah nilai composite reliability.suatu variabel atau konstruk dapat dikataka reliable ketika memiliki nilai $>0,5$. Berikut adalah tabel nilai composite reliability:

Nilai Composite Reliability

\begin{tabular}{|l|c|}
\hline \multicolumn{1}{|c|}{ Variabel } & $\begin{array}{c}\text { Composite } \\
\text { Reliability }\end{array}$ \\
\hline NPF & 1.000 \\
\hline P. Bagi Hasil & 0.687 \\
\hline P. Jual Beli & 1.000 \\
\hline Profitabilitas & 0.964 \\
\hline
\end{tabular}

Sumber : Olah Data SmartPLS Versi 3.0

Dari tabel diatas dapat diketahui bahwa nilai reliabilitas dari setiap konstruk memiliki nilai $>0,5$ sehingga memenuhi kriteria composite reliability dan dapat dikatakan jika data tersebut reliabel.

\section{Inner Model}

Pengujian inner model atau model struktural dilakukan untuk mengetahu hubugan antar konstruk, nilai signifikansi dan R-square dari suatu model penelitian. Pada uji inner model akan dilakukan pengujian yaitu uji goodness of fit dan uji hipotesis.

\section{Inner Model}

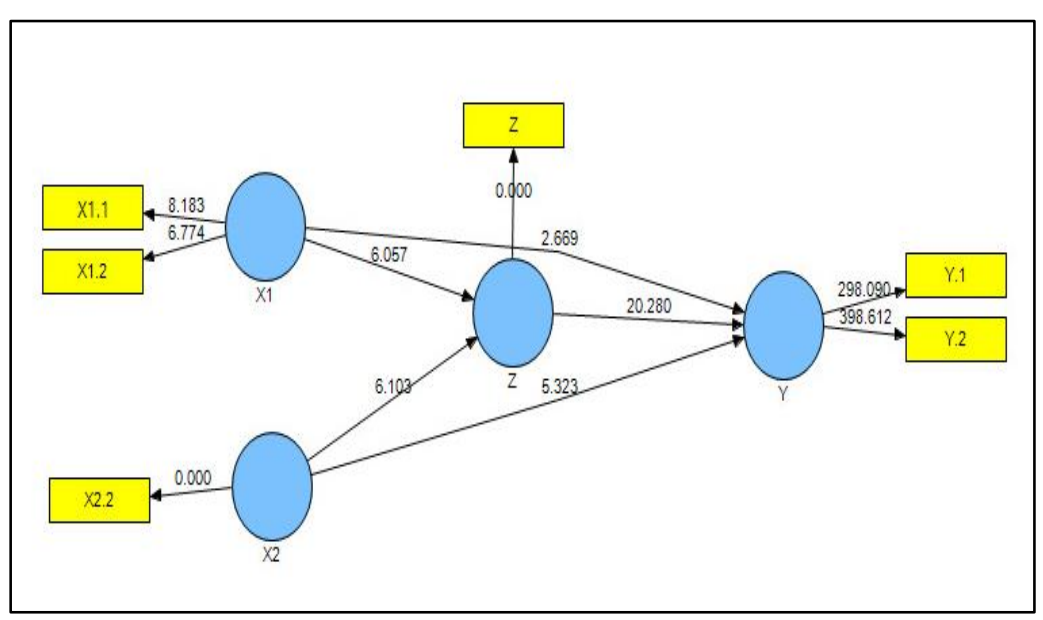




\section{Uji Coefficient Determination}

Pengujian coefficient determination (R-square) ini dilakukan dengan tujuan untuk mengukur seberapa banyak variabel endogen dipengaruhi oleh variabel lainnya dalam suatu penelitian. Semakin tinggi nilai $R$-square maka semakin baik nilai prediksi dari model yang diajukan. Nilai $R$-square 0,75 yang berarti model dalam kategori kuat, nilai 0,50 dalam kategori moderat, dan nilai diantara 0,25 dikatakan dalam kategori lemah. Berdasarkan pengolahan data yang telah dilakukan oleh peneliti dengan menggunakan program SmartPLS 3.0, diperoleh nilai sebagai berikut :

\section{Nilai $R$-Square}

\begin{tabular}{|l|c|}
\hline & R Square \\
\hline NPF & 0.068 \\
\hline Profitabilitas & 0.301 \\
\hline
\end{tabular}

Sumber : Olah Data SmartPLS Versi 3.0

Setelah mengetahui besar nilai $R$-Square tahap selanjutnya adalah pengujian goodness of fit. Penilaian goodness of fit dapat diketahui melalui nilai $Q$-Square. Semakin tinggi nilai $Q$ Square dalam suatu penelitian maka dapat menujukkan bahwa model tersebut dapat dikatakan baik. Ketentuan nilai $Q$-Square dalam suatu penelitian adalah $0<Q$-Square $<1$, semakin nilai $Q$-square mendekati 1 maka akan semakin baik. Adapun hasil dari perhitungan nilai $Q$-Square adalah sebagai berikut :

$$
\begin{aligned}
\text { Q-Square } & =1-\left[\left(1-R^{2} 1\right) \times\left(1-R^{2}\right)\right] \\
& =1-[(1-0,068) \times(1-0,301)] \\
& =1-0,651 \\
& =0,349
\end{aligned}
$$

Berdasarkan hasil perhitungan diatas, diperoleh nilai Q-Square sebesar 0,349. Nilai tersebut menujukkan bahwa nilai Q-Square memiliki nilai diatas nol, hal tersebut dapat menunjukkan bahwa model penelitian ini dapat dinyatakan telah memiliki goodness of fit yang baik.

\section{Uji Hipotesis}

Uji hipotesis dalam penelitian ini dilakukan dengan melihat nilai T-Statistics dan P-Values. Hipotesis penelitian dapat dinyatakan diterima apabila memiliki nilai $T$-statistics lebih dari $T$ - 
table atau T-statistics $>1$ 1,96. Berikut adalah hasil uji hipotesis yang diperoleh dalam penelitian ini melalui metode bootstrapping :

\section{Bootsrapping}

\begin{tabular}{|l|c|c|c|c|c|}
\hline & $\begin{array}{c}\text { Original } \\
\text { Sample } \\
\text { (0) }\end{array}$ & $\begin{array}{c}\text { Sample } \\
\text { Mean } \\
\text { (M) }\end{array}$ & $\begin{array}{c}\text { Standard } \\
\text { Deviation } \\
\text { (STDEV) }\end{array}$ & $\begin{array}{c}\text { Standard } \\
\text { Error } \\
\text { (STERR) }\end{array}$ & $\begin{array}{c}\text { T Statistics } \\
(|\mathbf{O} / \mathbf{S T D E V}| \text { ) }\end{array}$ \\
\hline X1 -> Y & 0.045 & 0.041 & 0.017 & 0.017 & 2.670 \\
\hline X1 -> Z & 0.168 & 0.164 & 0.028 & 0.028 & 6.058 \\
\hline X2 -> Z & 0.186 & 0.070 & 0.013 & 0.013 & 5.323 \\
\hline X2 -> Y & 0.070 & 0.189 & 0.030 & 0.030 & 6.103 \\
\hline Z -> Y & -0.565 & -0.561 & 0.028 & 0.028 & 20.280 \\
\hline
\end{tabular}

Sumber : Olah Data SmartPLS Versi 3.0

Dari tabel 4.8 dapat diketahui beberapa hasil analisis sebagai berikut :

1. Pengujian pengaruh antara pembiayaan bagi hasil terhadap profitabilitas memiliki nilai original sampel sebesar 0,045 dengan nilai T-statistic sebesar 2,670. Karena memiliki nilai $T$-statistic $>1,96$, maka terdapat pengaruh yang positif dan signifikan antara pembiayaan bagi hasil terhadap profitabilitas.

2. Pengujian pengaruh antara pembiayaan bagi hasil terhadap NPF memiliki nilai original sampel sebesar 0,168 dengan nilai $T$-statistic sebesar 6,058. Karena memiliki nilai $T$-statistic $>1,96$ maka terdapat pengaruh yang positif dan signifikan antara pembiayaan bagi hasil terhadap NPF.

3. Pengujian pengaruh antara pembiayaan jual beli terhadap NPF memiliki nilai original sampel sebesar 0,186 dengan nilai $T$-statistic sebesar 5,323. Karena memiliki nilai $T$ statistic $>1,96$, maka terdapat pengaruh yang positif dan signifikan antara pembiayaan jual beli terhadap NPF.

4. Pengujian pengaruh antara pembiayaan jual beli terhadap profitabilitas memiliki nilai original sampel sebesar 0,070 dengan nilai $T$-statistic sebesar 6,103. Karena memiliki nilai $T$-statistic $>1,96$ maka terdapat pengaruh yang positif dan signifikan antara pembiayaan jual beli terhadap profitabilitas.

5. Pengujian pengaruh antara NPF terhadap profitabilitas memiliki nilai original sampel sebesar -0,565 dengan nilai $T$-statistic sebesar 20,280. Karena memiliki nilai $T$ statistic $>1,96$ maka terdapat pengaruh yang negatif dan signifikan antara NPF terhadap profitabilitas. 


\section{Pembahasan Hasil Penelitian}

\section{Pengaruh pembiayaan bagi hasil terhadap profitabilitas}

Berdasarkan hasil uji variabel pembiayaan bagi hasil terhadap profitabilitas diperoleh nilai nilai $T$-statistic sebesar 2,670 dan nilai original sampel sebesar 0,045 maka dapat disimpulkan bahwa pembiayaan bagi hasil berpengaruh positif dan signifikan terhadap profitabilitas, sehingga $\mathrm{H}_{1}$ diterima. Hal ini sesuai dengan penelitian yang dilakukan oleh Maulida Nurul Baiti18 dan Dwi Wahyuningsih ${ }^{19}$ yang menyatakan bahwa pembiayaan bagi hasil berpengaruh positif terhadap profitabilitas. Hal ini berarti semakin tinggi tingkat pembiayaan bagi hasil yang disalurkan oleh bank kepada nasabah maka akan semakin meningkatkan profitabilitas pada bank tersebut.

\section{Pengaruh Pembiayaan Bagi Hasil terhadap NPF}

Berdasarkan hasil uji variabel pembiayaan bagi hasil terhadap NPF diperoleh nilai $T$ statistic sebesar 6,058 dan nilai original sampel sebesar 0,168 maka dapat disimpulkan bahwa pembiayaan bagi hasil berpengaruh positif dan signifikan terhadap NPF, sehingga $\mathrm{H}_{2}$ diterima. Hal ini sesuai dengan penelitian yang dilakukan oleh Lilis Sudarwati ${ }^{20}$ dan Maulida Nurul Baiti21yang menyimpulkan bahwa pembiayaan bagi hasil berpengaruh positif terhadap NPF. Hal ini berarti semakin tinggi tingkat pembiayaan bagi hasil yang disalurkan maka tingkat NPF juga akan semakin tinggi.

\section{Pengaruh Pembiayaan Jual Beli terhadap NPF}

Berdasarkan hasil uji variabel pembiayaan jual beli terhadap NPF diperoleh nilai nilai $T$ statistic sebesar 5,323 dan nilai original sampel sebesar 0,186 maka dapat disimpulkan bahwa pembiayaan jual beli berpengaruh positif dan signifikan terhadap NPF, sehingga $\mathrm{H}_{3}$ diterima. Hal ini sejalan dengan penelitian yang dilakukan oleh Lilis Sudarwati22 yang menjelaskan bahwa pembiayaan jual beli berpengaruh positif terhadap NPF. Hal ini berarti semakin tinggi tingkat pembiayaan jual beli yang disalurkan oleh bank maka akan semakin meningkatkan tingkat NPF pada suatu bank syariah.

\footnotetext{
${ }^{18}$ Maulida Nurul Baiti, Skripsi : "Pengaruh Pembiayaan Mudharabah, Musyarakah, dan Murabahah terhadap Profitabilitas Return On Equity (ROE) dengan Non Performing Financing (NPF) sebagai variabel Intervening pada Bank Umum Syariah di Indonesia” (Salatiga : IAIN Salatiga, 2019).

${ }^{19}$ Dwi Wahyuningsih, Skripsi : "Pengaruh Pembiayaan

${ }^{20}$ Lilis Sudarwati, Skripsi : "Pengaruh Pembiayaan...

${ }^{21}$ Maulida Nurul Baiti, Skripsi : "Pengaruh Pembiayaan

${ }^{22}$ Lilis Sudarwati, Skripsi : "Pengaruh Pembiayaan....
} 


\section{Pengaruh Pembiayaan Jual Beli terhadap Profitabilitas}

Berdasarkan hasil uji variabel pembiayaan jual beli terhadap profitabilitas diperoleh nilai T-statistic sebesar 6,103 dan nilai original sampel sebesar 0,070 maka dapat disimpulkan bahwa pembiayaan jual beli berpengaruh positif dan signifikan terhadap profitabilitas, sehingga $\mathrm{H}_{4}$ diterima. Hal ini sejalan dengan penelitian yang dilakukan oleh Dwi Wahyuningsih ${ }^{23}$ dan Lilis Sudarwati24 yang menjelaskan bahwa pembiayaan jual beli berpengaruh positif terhadap profitabilitas. Hal ini berarti semakin tinggi tingkat pembiayaan jual beli yang disalurkan oleh bank maka akan semakin meningkatkan tingkat profitabilitas pada bank tersebut.

\section{Pengaruh NPF terhadap Profitabilitas}

Berdasarkan hasil uji variabel NPF terhadap profitabilitas diperoleh nilai T-statistic sebesar 20,280 dan nilai original sampel sebesar -0,565 maka dapat disimpulkan bahwa pembiayaan jual beli berpengaruh negatif dan signifikan terhadap profitabilitas, sehingga $\mathrm{H}_{4}$ diterima. Hal ini sejalan dengan penelitian yang dilkukan oleh Novika Anisa Firdausi25, Budihariyanto, Afifudin, dan Junaidii ${ }^{26}$ yang menyatakan bahwa NPF berpengaruh negatif dan signifikan terhadap profitabiltas. Hal ini menujukkan bahwa semakin besar NPF maka akan berdampak pada penurunan profitabilitas.

\section{PENUTUP}

\section{Kesimpulan}

Dari hasil analisis data dan pembahasan yang telah dipaparkan pada bab-bab sebelumnya, maka didapatkan kesimpulan sebagai berikut :

1. Berdasarkan hasil pengujian hipotesis menunjukkan bahwa Pembiayaan Bagi Hasil (X1) berpengaruh positif dan signifikan terhadap Profitabilitas (Y) dikarenakan memiliki nilai original sampel sebesar 0,045 dengan nilai T-statistic sebesar 2,670.

\footnotetext{
${ }^{23}$ Dwi Wahyuningsih, Skripsi : "Pengaruh Pembiayaan

${ }^{24}$ Lilis Sudarwati, Skripsi : "Pengaruh Pembiayaan....................."

25 Novika Anisa Firdausi, Skripsi : "Pengaruh Capital Adequacy Rasio (CAR) dan Non Performing Financing (NPF) terhadap Profitabilitas dengan Financing To Deposit Rasio (FDR) sebagai Variabel Intervening pada Bank Umum Syariah di Indonesia” (Salatiga : IAIN Salatiga, 2020)

26 Budihariyanto, Afifudin, Junaidi, "Pengaruh Pembiayaan...
} 
2. Berdasarkan hasil pengujian menunjukkan bahwa Pembiayaan Bagi Hasil (X1) berpengaruh positif dan signifikan terhadap Non Performing Financing (Z) dikarenakan memiliki nilai original sampel sebesar 0,168 dengan nilai T-statistic sebesar 6,058.

3. Berdasarkan hasil pengujian menunjukkan bahwa Pembiayaan Jual Beli (X2) berpengaruh positif dan signifikan terhadap Non Performing Financing (Z) dikarenakan memiliki nilai original sampel sebesar 0,186 dengan nilai T-statistic sebesar 5,323.

4. Berdasarkan hasil pengujian menunjukkan bahwa Pembiayaan Jual Beli (X2) berpengaruh positif dan signifikan terhadap Profitabilitas $(Y)$ dikarenakan memiliki nilai original sampel sebesar 0,070 dengan nilai T-statistic sebesar 6,103.

5. Berdasarkan hasil pengujian menunjukkan bahwa Non Performing Financing (Z) berpengaruh negatif dan signifikan terhadap Profitabilitas (Y) dikarenakan memiliki nilai original sampel sebesar -0,565 dengan nilai T-statistic sebesar 20,280.

\section{Saran}

Dari hasil penelitian dan olah data yang telah dilakukan oleh peneliti memberikan data sebagai berikut :

\section{Bagi pihak Bank Umum Syariah}

Pihak Bank Umum Syariah diharapkan mampu meningkatkan kembali kualitas pengelolahan dana yang nantinya akan disalurkan dengan mempertimbangkan dan memperhitungkan berbagai faktor yang dinilai dapat mempengaruhi pembiayaan, serta harus lebih meningkatkan prinsip kehati-hatian dalam menyalurkan pembiayaan sehingga Non Performing Financing mampu diminimalisir.

\section{Bagi Peneliti Selanjutnya}

Peneliti selanjutnya diharapkan mampu menambah variabel penelitian, dimana variabel tersebut dinilai mampu membuat profitabilitas dalam bank umum syariah mengalami peningkatan meskipun nilai NPF dalam bank tersebut juga meningkat. Sehingga, peneliti selanjutnya mampu menjawab pernyataan yang tidak dapat dijawab dalam penelitian ini. 


\section{DAFTAR PUSTAKA}

Budihariyanto, Afifudin, Junaidi. 2018. Pengaruh Pembiayaan (Bagi Hasil dan Jual Beli), Financing To Deposit Ratio (FDR), dan Non Performing Financing (NPF) Terhadap Profitabilitas Bank Non Devisa Syariah. Jurnal Ekonomi Vol. 07 No. 04.

https://www.ojk.go.id/

K. Lubis, Suhrawardi. 2000. Hukum Ekonomi Islam. Jakarta : Sinar Grafika.

Kasmir. 2015. Dasar-Dasar Perbankan Edisi Revisi 2014. Jakarta: Raja Grafindo Persada.

M Jogiyanto, Hartono. 2009. Analisis dan Disain: Sistem Informasi: Pendekatan Tersturktur Teori dan Praktek Aplikasi Bisnis. Yogyakarta: C.V Andi Offset.

Mila Rosa, Neny Tri Indrianasari, Khoirul Ifa. 2019. Pengaruh Pembiayaan Jual Beli, Pembiayaan Bagi Hasil, Dan Rasio Non Performing Financing Terhadap Profitabilitas (Studi Empirs pada Bank Umum Syariah di Bursa Efek Indonesia Tahun 2012-2017". Jurnal Ekonomi Vol. 2.

Nurul Baiti, Maulida. 2019. Pengaruh Pembiayaan Mudharabah, Musyarakah, dan Murabahah terhadap Profitabilitas Return On Equity (ROE) dengan Non Performing Financing (NPF) sebagai variabel Intervening pada Bank Umum Syariah di Indonesia. Salatiga : IAIN Salatiga. Skripsi.

Sudarwati, Lilis. 2018. Pengaruh Pembiayaan Bagi Hasil dan Pembiayaan Jual Beli Terhadap Profitabilitas (ROA) dengan Non Performing Financing (NPF) sebagai Variabel Intervening. Salatiga : IAIN Salatiga. Skripsi.

Sugiyono. 2011. Metode Penelitian Kuantitatif, Kualitatif dan R\&D. Bandung : ALFABETA.

Sugiyono. 2013. Metode Penelitian Kombinasi (Mixed Methods). Bandung : Alfabeta.

Umam, Khotibul. 2016. Perbankan Syariah Dasar-dasar dan Dinamika Perkembangan di Indonesia. Jakarta: PT Raja Grafindo Persada.

Wahyuningsih, Dwi . 2019. Pengaruh Pembiayaan Jual Beli, Pembiayaan Bagi Hasil, Likuiditas, Dan Intellectual Capital Terhadap Profitabilitas. Surakarta : IAIN Surakarta. Skripsi.

Wangsawidjaja. 2012. Pembiayaan Bank Syariah. Jakarta : PT Gramedia Pustaka Utama.

Willy Abdilah dan Jogiyanto. 2015. Partial Least Square (PLS) Alternatif Struktural Equation Modeling (SEM) dalam Penelitian Bisnis. Yogyakarta: C.V Andi Offset.

Wiroso. 2011. Produk Perbankan Syariah. Jakarta : LPFE Usakti. 